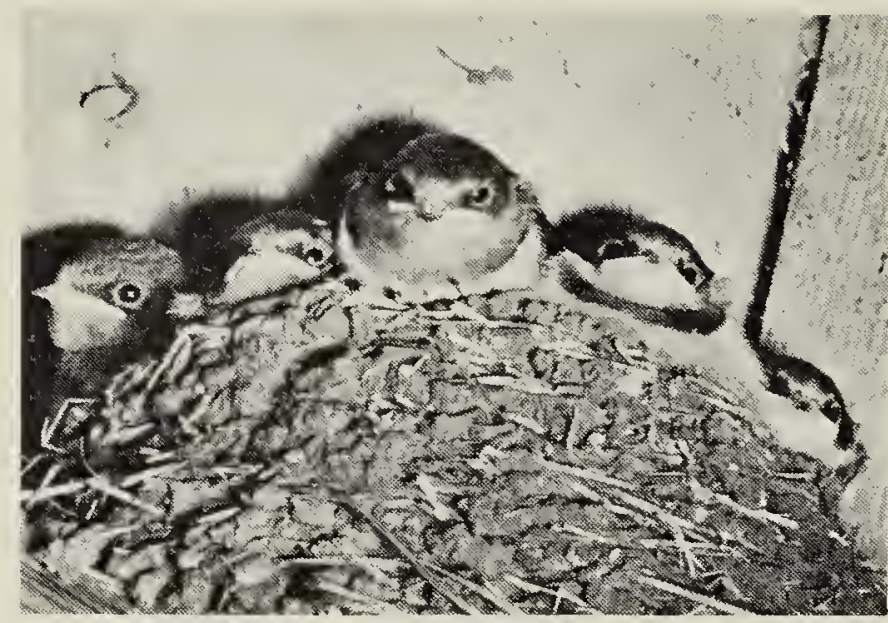

Photo by W. Yanchinskj Barn Swallow brood in nest

\section{A DETERMINED BARN SWALLOW}

by Bohdan Pylypec, Yellow Creek

In the late spring, I found a Barn Swallow nest in an abandoned granary. This nest was built of mud and was lined with grass and feathers. It was on a rafter six feet above the ground. The nest was probably used in the previous year since it had to be repaired. By June 20, five eggs were laid but a few days later, only four remained. One egg was found broken on the floor. About a week later, a heavy rain fell and the rain seeped through the roof. The nest became soggy and the bottom of the nest with the eggs and the lining fell on the floor. The swallows started repairing the nest, but instead of plastering the hole in the bottom of the nest, they merely put more mud on the top and covered the hole with a lining of grass and feathers. My father, who continued the observations on the nest while I was absent from home, saw that the nest wouldn't hold. Therefore, the next day he brought some mud to plaster the hole and a piece of board which was to hold the nest securely to the rafter. A metal sheet was also put on the roof so that the rain wouldn't seep through. He came too late, for the swallow had already laid an egg, and the egg, with the lining, fell through the hole in the bottom of the nest.
Although the swallows had failed twice, they started building another nest on the other side of the rafter. Three eggs were laid, but almost a week afterward, there were no eggs or lining in the nest. A small rodent had apparently scratched out the lining and eaten the eggs.

After failing three times, the swallows decided to give one more try. They repaired the first nest again and laid three eggs. These eggs all hatched and on September 3, the three young left the nest and were seen hawking insects with their parents. Thus, due to their determination and perseverance the swallows were able to raise a brood, but it had taken them four attempts to do so. These four attempts to raise a brood were made over a period of approximately 80 days. At least 30 visits were made by us to the nesting site, three-quarters of a mile from our home.

\section{INTERSPECIFIC NESTING ASSOCIATIONS OF SOME ARCTIC BIRDS}

by Spencer G. Sealy, Battleford

During the period July 8 to August 12,1965 , the writer had the pleasure of assisting J. P. Ryder in Canadian Wildlife Service studies of Ross' Goose (Anser rossii) in the Perry River region, Northwest Territories. Incidental observations of the avifauna of the area were made. The topography of this region is aptly summarized in the following excerpt from Hanson, Queneau and Scott (1956. The geography, birds and mammals of the Perry River region. Arctic Inst. N. Am. Sp. Pub. 3): "Glaciation and differential erosion have frequently produced a banded topography of parallel ridges separated by elongated roughly parallel lake or river courses." These hills or outcroppings rise to an altitude not 